Mohamed Naguib MB BCH M SC FFARCSI, Mohammed Abdullatif MB в СH MSC, Gamil H. Absood PH D

\title{
The optimal priming dose for atracurium
}

To determine the optimal priming dose for administration in divided doses, atracurium was given to 77 patients either in a single dose of $0.5 \mathrm{mg} \cdot \mathrm{kg}^{-1}$ or in an initial dose of $0.04,0.05,0.06,0.07,0.08$ or $0.09 \mathrm{mg}^{\circ} \mathrm{kg}^{-1}$, followed three minutes later by the remainder of the $0.5 \mathrm{mg} \cdot \mathrm{kg}^{-1}$ dose. Patients were anaesthetized throughout the study. When atracurium was given as a single bolus of 0.5 $\mathrm{mg} \cdot \mathrm{kg}^{-1}$, the mean time to complete neuromuscular block was 141.5 seconds. Administration in divided doses accelerated the onset time $(p<0.01)$, that is the time from the intubating dose to the complete suppression of train-of-four (TOF) response. The TOF ratio decreased slightly but statistically significantly following the priming doses. When the priming dose was $0.05 \mathrm{mg}^{-\mathrm{kg}^{-1}}$, the mean onset time was 70.9 seconds and priming with larger doses did not add any further advantage. It is concluded that $0.05 \mathrm{mg} \cdot \mathrm{kg}^{-1}$ appears to be the optimal priming dose for the administration of atracurium in divided doses. When $0.05 \mathrm{mg} \cdot \mathrm{kg}^{-1}$ is given three minutes before the intubating dose, tracheal intubation can be accomplished in less than 90 seconds.

Recently, attention has been focused on the usefulness of the "priming principle" in providing more rapid onset of tracheal intubation with non depolarizing muscle relaxants. ${ }^{1-5}$ The "priming principle" refers to the administration of a small (subparalyzing) dose of a non-depolarizing muscle relaxant a few minutes before the administration of the larger

\section{Key words}

INDUCTION: anaesthesia; INTUBATION: endotracheal; NEUROMUSCULAR RELAXANTS: atracurium.

From the Department of Anaesthesiology and the Biostatistics Unit, Department of Community Medicine, King Faisal University.

Address correspondence to: Dr. Mohamed Naguib, Department of Anaesthesiology, King Faisal University, King Fahd Hospital, P.O. Box 2208, Al-Khobar 31952, Saudi Arabia. (intubating) dose. ${ }^{6}$ The onset of neuromuscular blockade can be accelerated by this manoeuvre, and a non-depolarizing muscle relaxant can be made to provide a more rapid endotracheal intubation when succinylcholine is considered undesirable or contraindicated. $^{1-5}$

However, three questions have to be answered before recommending the routine application of the priming manoeuvre in everyday practice. First, what is the optimal time interval between the priming and the intubating dose? Secondly, what is the optimal priming dose? Lastly, what is the optimal intubating dose? ${ }^{6}$

Using atracurium, we have recently reported that the optimal time interval appears to be three minutes between the administration of the priming and intubating doses.'

In this study, we tried to identify the optimal priming dose for atracurium.

\section{Methods}

After institutional approval, 77 ASA physical status I or II patients undergoing elective surgical procedures were studied. All patients were free from neuromuscular, renal or hepatic disease and were not taking any drugs known to interfere with neuromuscular function. Informed consent was obtained. All patients were premedicated with diazepam $0.15 \mathrm{mg} \cdot \mathrm{kg}^{-1}$ orally 90 minutes preoperatively.

An intravenous infusion of lactated Ringer's solution in five per cent dextrose was established prior to induction. The ECG and nasopharyngeal temperature were monitored continuously by a Medishield Ml monitor. Blood pressure was measured every five minutes by an electronic oscillotonometer (Dinamap).

In all patients, anaesthesia was induced with fentanyl $2 \mu \mathrm{g} \cdot \mathrm{kg}^{-1}$, thiopentone $5 \mathrm{mg} \cdot \mathrm{kg}^{-1}$ and was maintained with 70 per cent nitrous oxide in oxygen and incremental doses of fentanyl or thiopentone, or both as required to maintain stable balanced anaesthesia. 
After induction of anaesthesia, the thumb of a restrained arm was attached to a force displacement transducer to record the response of the adductor pollicis to supramaximal stimulation of the ulnar nerve at the elbow via surface electrodes, using a Myotest peripheral nerve stimulator (Biometer) and a neuromuscular function analyzer with a continuous pen and paper recorder (Myograph 2000, Biometer). The preload tension on the thumb was maintained at $300 \mathrm{~g}$ throughout the investigation.

Four square wave impulses of $0.2 \mathrm{~ms}$ duration and $2 \mathrm{~Hz}$ frequency were repeated every ten seconds. After stabilization of the twitch recording, atracurium was injected into a rapidly running intravenous infusion. The same total dose of atracurium $0.5 \mathrm{mg} \cdot \mathrm{kg}^{-1}$, was given to all patients. Patients were allocated randomly to seven groups. Atracurium was administered as an initial dose of $0.04,0.05,0.06,0.07,0.08$ or $0.09 \mathrm{mg} \cdot \mathrm{kg}^{-1}$ and followed three minutes later by the rest of the dose in Groups I to VI respectively. In Group VII (controls) atracurium was administered as a single bolus dose.

The train-of-four (TOF) ratio (the amplitude of the fourth to the first evoked response; $T_{4} / T_{1}$ ) was noted before the administration of atracurium in all groups. The maximum effect of the priming dose on the TOF ratio was also recorded.

Onset time (time from the end of injection of the intubating dose to the development of complete depression of all four response to TOF stimulation) was determined. Tracheal intubation was performed immediately following complete TOF suppression in all groups by a single observer who was blinded to the patient groups. Intubating conditions were scored according to Fahey et al. ${ }^{7}$ Ventilation was controlled to maintain normocapnia and end tidal $\mathrm{CO}_{2}$ was monitored by Datex infra-red $\mathrm{CO}_{2}$ analyzer. Times from the injection of the intubating dose of atracurium to 10 and 20 per cent recovery of the first twitch $\left(T_{1}\right)$ of TOF were recorded.

\section{Statistics}

Results are expressed as mean $\pm \mathrm{SD}$. Statistical significance of the differences of the various parameters observed in different groups were determined with analysis of variance. Paired Student's t test was applied to compare the TOF ratios before and after the administration of the priming dose in each group. Intubating scores were compared using the
TABLE I Demographic data $(\mathrm{n}=11$ in all groups)

\begin{tabular}{llll}
\hline & $\begin{array}{l}\text { Age } \\
\text { (years) }\end{array}$ & $\begin{array}{l}\text { Weight } \\
(\mathrm{kg})\end{array}$ & $\begin{array}{l}\text { Sex } \\
(M / F)\end{array}$ \\
\hline Group I & $30.8 \pm 6.8$ & $63.0 \pm 10.7$ & $6 / 5$ \\
Group II & $27.3 \pm 4.3$ & $65.4 \pm 8.1$ & $6 / 5$ \\
Group III & $36.6 \pm 10.2$ & $58.0 \pm 10.9$ & $7 / 4$ \\
Group IV & $28.1 \pm 8$ & $58.7 \pm 7.2$ & $7 / 4$ \\
Group V & $31.3 \pm 9.9$ & $63.5 \pm 7$ & $6 / 5$ \\
Group VI & $27.3 \pm 6$ & $55.8 \pm 8.3$ & $7 / 4$ \\
Group VII & $31.1 \pm 7.6$ & $60.3 \pm 13$ & $6 / 5$ \\
\hline
\end{tabular}

Kruskal-Wallis test. The values were considered to be statistically significant when $p<0.05$.

\section{Results}

There were 11 patients in each group. There was no significant difference among the seven groups with respect to age, body weight and sex distribution (Table I).

The TOF ratio decreased significantly following the priming doses (Table II). In six patients in Groups V and VI (three patients in each group), the TOF ratio decreased to $0.46,0.65,0.72$ and 0.41 , $0.48,0.64$ respectively. The percentage reduction in TOF ratios in relation to the different priming doses is shown in the Figure. The reduction in TOF ratio was significantly greater $(p<0.01$ ) in Group VI when compared to Groups I, II, III and IV. Group $V$ showed also a greater reduction in TOF ratio $(p<0.01)$ when compared to Group I only.

The onset of neuromuscular block was faster $(p<0.01)$ in all groups $(\mathrm{l}-\mathrm{VI})$ who received atracurium in divided doses (Table III).

TABLE II The effect of priming dose on TOF ratios

\begin{tabular}{llll}
\hline & \multicolumn{3}{c}{ TOF ratios } \\
\cline { 2 - 3 } Group* & $\begin{array}{l}\text { Pose } \\
\left(m g \cdot \mathrm{kg}^{-1}\right)\end{array}$ & $\begin{array}{l}\text { Maximum effects } \\
\text { of priming doses }\end{array}$ & pt \\
\hline I & 0.04 & $0.97 \pm 0.01$ & $<0.025$ \\
II & 0.05 & $0.94 \pm 0.03$ & $<0.025$ \\
III & 0.06 & $0.95 \pm 0.05$ & $<0.025$ \\
IV & 0.07 & $0.95 \pm 0.02$ & $<0.005$ \\
V & 0.08 & $0.81 \pm 0.14$ & $<0.005$ \\
VI & 0.09 & $0.78 \pm 0.18$ & $<0.005$ \\
VII & - & - & - \\
\hline
\end{tabular}

$*_{n}=11$ in all groups.

tStudent's I test, when compared to the TOF ratios before injection of the priming doses. 
TABLE III Priming interval, intubating dose, onset time, intubating conditions and recovery of twitch height $\left(\mathrm{T}_{1}\right)$ to $10 \%$ and $20 \%$

\begin{tabular}{|c|c|c|c|c|c|c|c|c|c|}
\hline \multirow[b]{2}{*}{ Group } & \multirow{2}{*}{$\begin{array}{l}\text { Priming } \\
\text { interval } \\
\text { (min) }\end{array}$} & \multirow{2}{*}{$\begin{array}{l}\text { Intubating } \\
\text { dose } \\
\left.\text { (mg. } \mathrm{kg}^{-1}\right)\end{array}$} & \multirow{2}{*}{$\begin{array}{l}\text { Onset time } \\
\text { (seconds) }\end{array}$} & \multicolumn{4}{|c|}{$\begin{array}{l}\text { Intubating } \\
\text { conditions }\end{array}$} & \multirow{2}{*}{$\begin{array}{l}10 \% \text { Recovery } \\
\text { of } T \text {, (min) }\end{array}$} & \multirow{2}{*}{$\begin{array}{l}20 \% \text { Recover } \\
\text { of } T_{1}(\min )\end{array}$} \\
\hline & & & & 0 & 1 & 2 & 3 & & \\
\hline I & 3 & 0.46 & $93.2 \pm 20.4^{*}$ & 3 & 4 & 4 & 0 & $38.4 \pm 6.1$ & $40.7 \pm 6.3$ \\
\hline II & 3 & 0.45 & $70.9 \pm 11.7^{*}$ & 3 & 2 & 6 & 0 & $37.1 \pm 5.0$ & $40.4 \pm 5.6$ \\
\hline III & 3 & 0.44 & $77.9 \pm 18.1^{*}$ & 5 & 4 & 2 & 0 & $37.2 \pm 7.4$ & $41 \pm 8$ \\
\hline IV & 3 & 0.43 & $74.5 \pm 25.3^{*}$ & 2 & 7 & 2 & 0 & $35.9 \pm 6.9$ & $38.7 \pm 6.8$ \\
\hline V & 3 & 0.42 & $75.7 \pm 15.2 *$ & 4 & 3 & 4 & 0 & $36.7 \pm 7.5$ & $40.3 \pm 7.7$ \\
\hline VI & 3 & 0.41 & $73.1 \pm 33.8 *$ & 3 & 5 & 3 & 0 & $35 \pm 9$ & $38.1 \pm 8.7$ \\
\hline VII & - & 0.5 & $141.4 \pm 37.7$ & 3 & 4 & 4 & 0 & $33.9 \pm 4.5$ & $36.1 \pm 4.6$ \\
\hline
\end{tabular}

*The onset times were significantly $(p<0.01$ ) faster in the groups who received atracurium in divided doses. $\mathrm{n}=11$ in all groups.

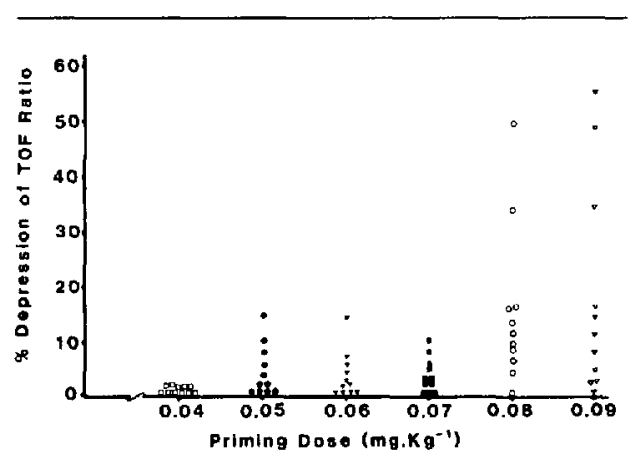

FIGURE Effect of different priming doses of atracurium on the TOF ratio. Each group included 11 patients.

Intubating conditions were acceptable in all patients (intubating score of two or less). The size of the priming dose had no influence on the intubating conditions. There was no significant difference in the intubating score between the groups (Table III).

The duration of the neuromuscular blockade as assessed by times to 10 and 20 per cent recovery of $T$, was not significantly affected by the size of the priming dose.

\section{Discussion}

Paton and Waud $^{8}$ in 1967 pointed out that the margin of safety of the neuromuscular transmission is such that only $20-25$ per cent of the postsynaptic receptors need to be free for transmission to occur. The usefulness of this finding had not been recognized until 1983, when Gergis et al. ${ }^{2}$ reported that the prior administration of a sub-paralyzing (or priming) dose of atracurium beforehand, accelerated the onset of the intubating dose. The hypothesis is that a small dose of a non-depolarizing muscle relaxant will partially occupy the post-junctional receptors, therefore allowing a more rapid and profound effect of the second (intubating) dose. ${ }^{6}$

Increasing the priming dose, as expected, will shorten the onset time ${ }^{3}$ However, the limiting point is the appearance of the undesirable signs of weakness in the awake patient. Engbaeck et al. ${ }^{9}$ found in awake healthy volunteers that 0.015 $\mathrm{mg} \cdot \mathrm{kg}^{-1}$ vecuronium was associated with an unacceptably high frequency of signs and symptoms of partial neuromuscular blockade. This observation has been reported with other non-depolarizing muscle relaxants. ${ }^{9-11}$

It has been shown that 70-75 per cent of the end-plate receptors must be occupied by relaxant before the TOF ratio is affected. ${ }^{12}$ In this study, priming doses in the range of $0.04 \mathrm{mg} \cdot \mathrm{kg}^{-1}$ to $0.09 \mathrm{mg} \cdot \mathrm{kg}^{-1}$ were associated with small but statistically significant reductions in the TOF ratios. In addition, TOF ratios in six patients who received atracurium $0.08 \mathrm{mg} \cdot \mathrm{kg}^{-1}$ or $0.09 \mathrm{mg} \cdot \mathrm{kg}^{-1}$ (three in each group), decreased to $0.46,0.65,0.72$ and $0.41,0.48,0.64$ respectively. Ali et al. ${ }^{13}$ reported that the magnitude of changes in the respiratory parameters at a TOF ratio of 0.6 or higher was minor and of no clinical importance; however, all volunteers in their study experienced diplopia and weakness of the facial muscles.

As already indicated, the priming dose should accelerate the onset of neuromuscular blockade of 
the second (intubating) dose. Atracurium doses of $0.04-0.09 \mathrm{mg} \cdot \mathrm{kg}^{-1}$ were associated with acceleration of the onset time. When the priming dose was $0.04 \mathrm{mg} \cdot \mathrm{kg}^{-1}$, the mean onset time was more than 90 seconds, therefore, the optimal priming dose for atracurium appears to be between 0.05-0.07 $\mathrm{mg} \cdot \mathrm{kg}^{-1}$ (Figure).

There was no significant difference in the intubating conditions between the seven groups studied. Therefore, priming with doses larger than 0.05 $\mathrm{mg} \cdot \mathrm{kg}^{-1}$ did not offer any further advantage. The use of priming doses in this study, as in others reported, ${ }^{1-5}$ did not provide ideal intubating conditions. However, the intubating conditions in this and in other studies ${ }^{1-5}$ were acceptable for most clinical situations.

The effect of the priming doses on the duration of action of non-depolarizing muscle relaxants is controversial. ${ }^{3.5}$ In this study as well as in the previous one ${ }^{1}$ there was no significant difference in the duration of neuromuscular block whether atracurium was given as a single bolus dose or in divided doses.

In this study, priming doses in the range of 0.04 to $0.09 \mathrm{mg} \cdot \mathrm{kg}^{-1}$ were associated with a slight but statistically significant reduction in the TOF ratios, which accelerated the onset of the intubating dose and facilitated rapid endotracheal intubation. The optimal priming dose for the administration of atracurium in divided doses appears to be 0.05 $\mathrm{mg} \cdot \mathrm{kg}^{-1}$

\section{Acknowledgements}

We wish to express our gratitude to Professor Richard I. Bodman for his support and advice, and to Mr. A. Halim Kamel for photography.

\section{References}

1 Naguib M, Gyasi HK, Abdullatif M, Absood GH. Rapid tracheal intubation with atracurium. A comparison of priming intervals. Can Anaesth Soc $J$ 1986; 33: 150-6.

2 Gergis SD, Sokoll MD, Mehta M, Keminotsu O, Rudd GD. Intubation conditions after atracurium and suxamethonium. Br J Anaesth 1983; 55 (Suppl 1): $83 S-6 S$

3 Schwarz $S$, llias $W$, Lackner $F$, Mayrhofer $O$, Foldes $F F$. Rapid tracheal intubation with vecuronium. The priming principle. Anesthesiology 1985; 62: 389-91.
4 Mehta MP, Choi W, Gergis SD, Sokoll MD, Adolphson $A$. Facilitation of rapid sequence endotracheal intubations with divided doses of nondepolarizing neuromuscular blocking drugs. Anesthesiology $1985 ; 62: 392-5$.

5 Doherty WG, Breen PJ, Donati F, Bevan RD. Accelerated onset of pancuronium with divided doses. Can Anaesth Soc J 1985; 32: 1-4.

6 Miller $R D$ (Editorial). The priming principle. Anesthesiology 1985; 62: 381-2.

7 Fahey MR, Morris, RB, Miller RD, John YJ, Cronelly $R$, Gencarelli $P$. Clinical pharmacology of ORG NC 45 (Norcuron): a new nondepolarizing muscle relaxant. Anesthesiology 1981; 55: 6-11.

8 Paton WDM, Waud DR. The margin of safety of neuromuscular transmission. J Physiol (Lond.) 1967; 191: 59-90.

9 Engbaeck J, Howardy-Hansen P, Ording H, VibyMogensen J. Precurarization with vecuronium and pancuronium in awake, healthy volunteers: the influence on neuromuscular transmission and pulmonary function. Acta Anaesthesiol Scand 1985; 29 : 117-20.

10 Howardy-Hansen P, Chraemmer-Jorgensen B, Ording $H$, Viby-Mogensen J. Pretreatment with nondepolarizing muscle relaxants: the influence on neuromuscular transmission and pulmonary function. Acta Anaesthesiol Scand 1980; 24: 419-22.

11 Rao TLK, Jacobs HK. Pulmonary function following "pretreatment" doses of pancuronium in volunteers. Anesth Analg 1980; 59: 659-61.

12 Waud BE, Waud DR. The relation between the response to "train-of-four" stimulation and receptor occlusion during competitive neuromuscular block. Anesthesiology 1972; 37: 413-6.

13 Ali HH, Wilson RS, Savarese JJ, Kitz RJ. The effect of tubocurarine on indirectly elicited train-offour muscle response and respiratory measurements in humans. Br J Anaesth 1975; 47: 570-4. 
Résumé

Afin de déterminer la dose optimale d'amorce (priming dose) pour une administration d doses filées, l'atracurium a été donné à 77 patients soit en une seule dose de $0.5 \mathrm{mg} \cdot \mathrm{kg}^{-1}$ ou en une dose initiale de 0.04, 0.05, 0.06, $0.07,0.08 \mathrm{ou} 0.09 \mathrm{mg}^{\mathrm{kg}} \mathrm{kg}^{-1}$ suivi trois minutes plus tard par le restant de la dose de $0.5 \mathrm{mg} \cdot \mathrm{kg}^{-1}$. Les patients étaient anesthésiés tout au long de l'étude. Quand l'atracurium était donné en une dose unique de 0.5 $\mathrm{mg} \cdot \mathrm{kg}^{-1}$ le temps moyen nécessaire pour un bloc neuromusculaire complet était de 141.5 secondes. L'administration à dose flée a accéléré le temps d'installation ( $p<$ $0.01)$, ce temps est calculé à partir de l'administration de la dose d'intubation jusqu'à la suppression complète de la réponse à londée-de-quatre (TOF). Le ratio de l'ondée-de-quatre a diminué légèrement mais d'une façon statistiquement significative après les doses d'amorce. Quand la dose d' amorce était de $0.05 \mathrm{mg} \cdot \mathrm{kg}^{-1}$ le temps d'installation moyen était de 70.9 secondes et l'amorçage avec des doses plus grandes n'a pas ajouté d'autres avantages. Il est conclut que $0.05 \mathrm{mg} \cdot \mathrm{kg}^{-1}$ apparait comme étant la dose d'amorce optimale pour l'administration de l'atracurium à doses filées. Quand $0.05 \mathrm{mg} \cdot \mathrm{kg}^{-1}$ était administré trois minuies avant la dose d'intubation, l'intubation pouvait être accomplie en moins de 90 secondes. 